\title{
EVALUASI MANAJEMEN BERBASIS SEKOLAH DI SEKOLAH DASAR NEGERI KABUPATEN SEMARANG
}

\author{
Rukayah \\ Alumni Program Pascasarjana Magister Manajemen Pendidikan \\ FKIP Universitas Kristen Satya Wacana \\ rukayah.spd@gmail.com
}

Bambang Ismanto

Program Pascasarjana Magister Manajemen Pendidikan

FKIP Universitas Kristen Satya Wacana

bambang.ismanto@staff.uksw.edu

\begin{abstract}
This study aimed to evaluate the implementation of school based management in SD Negeri Genuk 01 District West Ungaran in terms of context, input, process and product. This study was qualitative evaluative research using CIPP (Context, Input, Process, Product) model of evaluation developed by Stufflebeam. Data collection techniques used were interviews, observation and documentation. Test validity of data using triangulation technique. The results showed that: 1) from the context evaluation, school based management is needed by all stakeholders of the school to improve the quality of education; 2) from the input evaluation, human resources, curriculum, facilities, and funds were sufficient and ready to be used for the implementation of the school based management in primary School Genuk 01; 3) from the process evaluation, the implementation of school based management was not fully in accordance with the plan, especially in the decision making process and the learning process; 4) from the product evaluation, product (output) produced has not been as expected. It is therefore recommended that the school based management program continued with improvements in program implementation process.
\end{abstract}

Keywords: Evaluation program, CIPP Model, School Based Management.

\section{PENDAHULUAN}

Manajemen merupakan komponen integral dan tidak dapat dipisahkan dari proses pendidikan secara keseluruhan. Karena tanpa manajemen tidak mungkin tujuan pendidikan dapat diwujudkan secara optimal, efektif dan efisien. Dalam kerangka inilah tumbuh kesadaran akan pentingnya Manajemen Berbasis Sekolah (MBS), yang memberikan kewenangan penuh kepada sekolah dan guru dalam mengatur pendidikan dan pengajaran, 
merencanakan, mengorganisasi, mengawasi, mempertanggung jawabkan, mengatur, memimpin sumber-sumber daya insani serta barang-barang untuk membantu pelaksanaan pembelajaran yang sesuai dengan tujuan sekolah (Mulyasa 2012:20). Hal ini berarti bahwa sekolah sebagai suatu organisasi membutuhkan manajemen yang sesuai dengan kondisi setempat sehingga dapat mendorong profesionalisme guru dan kepala sekolah dalam mewujudkan tujuan pendidikan.

MBS merupakan program kebijakan nasional yang menjadi prioritas pemerintah dalam upaya meningkatkan mutu pendidikan di tingkat Sekolah Dasar/Madrasah Ibtidaiyah. Merupakan model manajemen yang memberikan otonomi yang lebih luas kepada sekolah untuk mengelola sumberdaya dan sumber dana yang ada. Pengalokasiannya sesuai dengan prioritas kebutuhan setempat serta mendorong sekolah untuk dapat mengambil keputusan yang berkaitan dengan penyelenggaraan pendidikan secara bersama dari semua warga sekolah dan masyarakat.

Keterlibatan masyarakat dalam MBS dimaksudkan agar partisipasi dan dukungan masyarakat dapat membantu serta mengontrol pengelolaan pendidikan. Rohiat (2012:47), menjelaskan bahwa: Manajemen Berbasis Sekolah adalah model pengelolaan yang memberikan otonomi (kewenangan dan tanggung jawab yang lebih besar kepada sekolah), memberikan fleksibilitas/keluwesan kepada sekolah, mendorong partisipasi secara langsung dari warga sekolah (guru, siswa, kepala sekolah, karyawan), dan masyarakat (orangtua siswa, tokoh masyarakat, ilmuan, pengusaha), dan meningkatkan mutu sekolah berdasarkan kebijakan pendidikan nasional serta peraturan perundang-undangan yang berlaku.

Menurut Hidayat dan Machali (2012:53), "MBS merupakan paradigma baru dalam manajemen pendidikan yang memberi otonomi luas pada sekolah/madrasah, dan pelibatan masyarakat dalam kerangka kebijakan pendidikan nasional". Hal ini sejalan dengan pernyataan dari (Rahardjo, 2004:3), bahwa: MBS adalah model manajemen yang memberikan otonomi lebih besar kepada sekolah dan mendorong pengambilan keputusan bersama/partisipatif dari semua warga sekolah dan masyarakat untuk mengelola sekolah dalam rangka meningkatkan mutu pendidikan berdasarkan kebijakan pendidikan nasional.

Dengan MBS kepala sekolah selaku pengelola lembaga pendidikan lebih leluasa menyusun dan melaksanakan program pendidikan sesuai dengan kebutuhan sekolah. Selain itu melalui MBS kerjasama dan partisipasi masyarakat serta peran sumber daya manusia yang ada di sekolah dapat ditingkatkan, sehingga tujuan dari MBS dalam peningkatan layanan 
pendidikan secara demokratis, transparan dan akuntabel dapat dicapai dengan lebih efisien dan efektif sesuai tujuan pendidikan nasional.

MBS bertujuan untuk meningkatkan kinerja sekolah yang meliputi peningkatan kualitas, efektivitas, efisien, produktivitas, dan inovasi pendidikan melalui pemberian kewenangan dan tanggung jawab lebih besar kepada sekolah yang dilaksanakan dengan prinsip pengelolaan yang baik, yaitu partisipasi, transparansi, dan akuntabilitas (Rohiat, 2012:49). Peningkatan kualitas dan produktivitas dapat diperoleh antara lain melalui partisipasi orang tua dan masyarakat, pengelolaan kelas, peningkatan profesionalisme guru dan kepala sekolah. Peningkatan efektivitas dan efisiensi diperoleh dari keleluasaan yang diberikan untuk mengelola sumberdaya yang ada.

MBS merupakan proses kegiatan yang dilakukan secara bersama antara pihak sekolah dan masyarakat dalam bidang pendidikan. Sumberdaya manusia yang ada diberdayakan dan dikelola untuk mencapai tujuan pendidikan. Melalui MBS diharapkan sekolah dapat meningkatkan kemampuannya dalam merencanakan, mengelola, dan menyelenggarakan pendidikan di sekolah sehingga dapat meningkatkan mutu pendidikan.

Untuk mencapai tujuan MBS secara maksimal dibutuhkan peran dari berbagai pihak, baik pejabat dinas pendidikan, para pengawas sekolah, kepala seko-lah, para guru dan siswa di sekolah maupun masyarakat dan orang tua siswa.

MBS memberikan kebebasan dan kekuasaan yang besar kepada sekolah, yang tentu saja disertai dengan seperangkat tanggung jawab (Mulyasa 2012; Hidayat \& Machali 2012). Pemberian otonomi kepada sekolah sebuah tanggung jawab untuk mengelola sumberdaya yang ada dan mengembangkan strategi peningkatan mutu melalui MBS yang disesuaikan dengan kondisi setempat.

Selain dapat meningkatkan mutu pendidikan, MBS juga dapat meningkatkan kemandirian, fleksibilitas, partisipasi, keterbukaan, kerjasama, akuntabilitas, dan inisiatif sekolah dalam mengelola pendidikan. Di sisi lain MBS dapat meningkatkan kepedulian warga sekolah dan masyarakat dalam penyelenggaraan pendi-dikan melalui pengambilan keputusan bersama. Manfaat lain dari MBS adalah meningkatkan tanggung jawab sekolah kepada orang tua, masyarakat, dan pemerintah tentang mutu sekolahnya serta dapat meningkatkan kompetisi yang sehat antar sekolah tentang mutu pendidikan yang akan dicapai.

Karakeristik MBS perlu dipahami dan dikuasai oleh kepala sekolah selaku pemimpin lembaga dan akan menerapkannya bersama sumber daya manusia yang ada di sekolah. 
Karakteristik dimaksud meliputi seluruh komponen pendidikan yang meliputi input, proses dan output (Depdiknas 2004; Rohiat 2012).

Rahardjo (2004:11), menyebutkan bahwa Input Pendidikan memiliki karakteristik sebagai berikut: (1) Memiliki kebijakan, tujuan dan sasaran program yang jelas, (2) Sumberdaya tersedia dan jelas, (3) Staf yang kompeten dan berdedikasi yang tinggi, (4) Memiliki harapan prestasi yang tinggi, (5) Fokus pada pelanggan, (6) Manajemen.

Sedangkan sekolah yang efektif menurut Rahardjo (2004:9) memiliki kualitas proses pendidikan sebagai berikut: (1) Proses Belajar Mengajar yang efektivitasnya tinggi; (2) Kepemimpinan sekolah yang tangguh; (3) Lingkungan sekolah yang aman, tertib, dan nyaman; (4) Pengelolaan tenaga kependidikan yang efektif; (5) Sekolah memiliki budaya mutu; (6) Sekolah memiliki kebersamaan; (7) Sekolah memiliki kewenangan; (8) Partisipasi warga sekolah dan masyarakat; (9) Keterbukaan (transparasi) manajemen; (10) Sekolah memiliki kemauan untuk berubah; (11) Sekolah melakukan evaluasi dan perbaikan; (12) Sekolah responsif dan antisipatif terhadap kebutuhan; (13) Komunikasi yang baik; (14) Sekolah memiliki akuntabilitas. Output atau hasil yang diharapkan adalah prestasi sekolah yang dihasilkan melalui proses pembela-jaran dan manajemen sekolah. Output dapat berupa prestasi akademik dan non akademik. Prestasi aka-demik misalnya: hasil US, lomba karya ilmiah remaja. Dan output non akademik, berupa keingintahuan yang tinggi, harga diri, kejujuran, kerjasama yang baik, toleransi, kedisiplinan, prestasi olahraga, kesenian dari para peserta didik dan sebagainya.

Penegasan tentang Implementasi MBS dituangkan dalam UU Sisdiknas Nomor 20 tahun 2003 pasal 51 ayat 1 bahwa pengelolaan satuan pendidikan anak usia dini, pendidikan dasar dan menengah dilaksanakan berdsarkan standar pelayanan minimal dengan prinsip MBS. Selain itu Implementasi MBS di semua satuan pendidikan formal semakin jelas dan tegas dengan dikeluarkannya kebijakan pemerintah melalui UU nomor 32 tahun 2004 tentang Pemerintah Daerah dan PP nomor 25 tahun 2000 tentang Pembagian Kewenangan Pemerintah Pusat dan Otonomi Daerah. Dengan demikian terjadi pergeseran kewenangan dan keleluasaan dalam penyelenggaraan seluruh bidang kehidupan, termasuk bidang pendidikan.

Sebagai bentuk pengelolaan pendidikan, dalam pelaksanaannya MBS masih perlu dimantapkan dan disempurnakan secara berkesinambungan berdasarkan kelemahan dan kekurangan yang ada sehingga MBS dapat dilaksanakan dengan baik. Untuk mengetahui kelemahan dan kekurangan tersebut diperlukan evaluasi terhadap implementasi MBS secara 
menyeluruh dari setiap komponen. Wirawan (2011:17), mengungkapkan bahwa semua program perlu dievaluasi untuk menentukan apakah layanan atau intervensinya telah mencapai tujuan yang ditetapkan. Demikian pula MBS yang telah dilaksanakan di sekolah perlu dievaluasi guna mengetahui tingkat kemajuan sekolah tersebut sehubungan dengan sasaran-sasaran yang telah ditetapkan

Evaluasi adalah kegiatan untuk mengumpulkan informasi tentang bekerjanya sesuatu, yang selanjutnya informasi tersebut digunakan untuk menentukan alternatif yang tepat dalam mengambil sebuah keputusan (Arikunto \& Jabar 2008:2). Sementara itu menurut Tyler (1950 dalam Tayibnapis (2008:3), evaluasi adalah proses yang menentukan sampai sejauh mana tujuan pendidikan dapat dicapai.

Ditegaskan oleh Patton (2006:251), bahwa evaluasi adalah koleksi, analisis, dan penafsiran yang sistematis atas informasi tentang kegiatan dan hasil program nyata sesuai rencana untuk orang yang berkepentingan guna membuat keputusan tentang aspek spesifik seperti apa program itu berjalan dan meningkatkan program. Berdasarkan pendapat tersebut di atas maka dapat disimpulkan bahwa evaluasi adalah suatu kegiatan untuk menentukan sejauh mana tujuan dari suatu program dapat dicapai.

Evaluasi merupakan bagian yang tak terpisahkan dalam pelaksanaan MBS. Evaluasi merupakan tahapan dalam MBS yang merupakan kegiatan penting untuk mengetahui kemajuan atau hasil yang dicapai sekolah dalam melaksanakan fungsinya sesuai dengan rencana yang sudah disusun oleh masing-masing sekolah. Untuk itu dipandang perlu bagi penulis untuk meneliti lebih lanjut mengenai MBS, khususnya evaluasi MBS di SD Negeri Genuk 01 Kecamatan Ungaran Barat, Kabupaten Semarang.

Model evaluasi yang digunakan dalam penelitian ini adalah model evaluasi CIPP yang dikembangkan oleh Daniel Stufflebeam tahun 1966. Menurut Daniel Stufflebeam (2003 dalam Wirawan 2011:92), model CIPP terdiri dari empat jenis evaluasi, yaitu: Context Evaluation, Input Evaluation, Process Evaluation, dan Product Evaluation.

Context Evaluation (Evaluasi Konteks), yaitu evaluasi untuk mengidentifikasi dan menilai kebutuhan-kebutuhan yang mendasari disusunnya suatu program. Orientasi utama dari evaluasi konteks adalah mengidentifikasi latar belakang perlunya mengadakan perubahan atau munculnya program dari beberapa subjek yang terlibat dalam pengambilan keputusan. Apakah tujuan dan prioritas program telah dirancang berdasarkan analisis kebutuhan. Input Evaluation (Evaluasi Input), yaitu evaluasi yang dilaksanakan untuk mengidentifikasi dan menilai segala unsur yang tersedia karena dibutuhkan untuk berlangsungnya suatu proses. 
Unsur tersebut harus ada sebelum program dimulai. Dalam evaluasi input pada dasarnya untuk mem-pertanyakan apakah input-input pendidikan sudah siap dan memadai untuk digunakan baik dari segi kualitas maupun kuantitasnya. Komponen input dalam MBS meliputi: sumberdaya manusia (guru, kepala sekolah, tata usaha, peserta didik), kurikulum, sarana dan peralatan yang mendukung, serta dana dan anggaran sekolah. Process Evaluation (Evaluasi Proses), yaitu: evalu-asi yang bertujuan untuk mengakses pelaksanaan program apakah sesuai dengan rencana. Dalam MBS Unsur yang dievaluasi adalah: proses pengambilan keputusan, proses pengelolaan program, proses bela-jar mengajar, proses evaluasi sekolah. Evaluasi proses adalah untuk mempertanyakan apakah proses pengelolaan terhadap input sudah sesuai dengan yang diharapkan atau sudah terbukti baik. Product Evaluation (Evaluasi Produk), yaitu evaluasi yang dilakukan guna untuk melihat ketercapaian atau keberhasilan suatu program dalam mencapai tujuan yang telah ditentukan sebelumnya. Dalam evaluasi produk pada dasarnya untuk mempertanyakan apakah sasaran yang ingin dicapai pada program MBS sudah terwujud. Adapun hasil dari pelaksanaan program berupa prestasi akademik dan non akademik. Fokus dari evaluasi produk adalah untuk mengevaluasi sejauh mana yang diharapkan telah dicapai, baik dari segi kualitas, kuantitas, maupun waktunya.

Tujuan dari penelitian ini adalah: (1) Mengevaluasi konteks MBS di SD Negeri Genuk 01 Kecamatan Ungaran Barat; (2) Mengevaluasi input MBS di SD Negeri Genuk 01 Kecamatan Ungaran Barat; (3) Mengevaluasi proses MBS di SD Negeri Genuk 01 Kecamatan Ungaran Barat; (4) Mengevaluasi produk MBS di SD Negeri Genuk 01 Kecamatan Ungaran Barat. Sedangkan manfaat dari penelitian ini adalah: (1) Bagi Kepala sekolah, guru, komite sekolah diharapkan menjadi bahan masukan dan evaluasi yang membangun dalam meningkatkan kualitas pendidikan di sekolah; (2) Bagi Dinas Pendidikan dan Kebudayaan, diharapkan dapat menjadi bahan pertimbangan dalam kegiatan evaluasi dan pengambilan kebijakan lebih lanjut dalam upaya peningkatan kualitas pendidikan melalui MBS di Kabupaten Semarang; (3) Bagi masyarakat, diharapkan dapat mendukung sarana prasarana sekolah serta menciptakan suasana lingkungan yang kondusif dan nyaman untuk mendukung pembelajaran yang optimal.

\section{METODE PENELITIAN}

Jenis penelitian yang digunakan merupakan penelitian evaluatif dengan menggunakan pendekatan deskriptif kualitatif. Model evaluasi yang digunakan adalah model CIPP (Context, Input, Process, Product) yang dikembangkan oleh Stufflebeam. Keberhasilan dalam 
implementasi program dilihat secara komprehensif yang meliputi konteks, input, proses, dan produk. Sedangkan Teknik pengumpulan data pada penelitian ini menggunakan wawancara, observasi, studi dokumentasi, focus group discussion (FGD).

\section{ANALISIS DATA}

Data yang terkumpul dalam penelitian ini dianalisis menggunakan model evaluasi CIPP (Context, Input,Process,Product). Data yang diperoleh berasal dari hasil wawancara dengan narasumber, observasi, dan juga mempelajari dokumen dari SD Negeri Genuk 01 Ungaran Barat, Kabupaten Semarang. Selanjutnya hasil penelitian dirangkum, dipilah, kategorisasi dan pemaknaan data sesuai fokus pembahasan. Penyajian data dilakukan dalam bentuk teks yang bersifat naratif, dan teks dialog dari hasil wawancara. Setelah itu baru dilakukan penarikan kesimpulan

\section{HASIL DAN PEMBAHASAN}

SD Negeri Genuk 01 terletak di Jl. Letjen S. Parman No. 108 Kelurahan Genuk Kecamatan Ungaran Barat, Kabupaten Semarang. Sekolah ini dibangun di atas tanah seluas $1.705 \mathrm{~m} 2$ yang letaknya sangat strategis, karena selain berada di perbatasan antara Kelurahan Gedanganak dan Kelurahan Genuk juga terletak di tengah-tengah pemukiman penduduk. Untuk mencapai sekolah ini juga sangat mudah, dapat ditempuh dengan berjalan kaki atau menggunakan kendaraan.

Visi SDN Genuk 01 adalah "Maju dalam prestasi berdasarkan iman dan taqwa serta peduli terhadap lingkungan", Untuk mencapai visi tersebut SDN Genuk 01 menyusun misi sebagai berikut: (a) Melaksanakan pembelajaran secara "RILEK" (Rekreatif, Interaktif Lugas, Efektif dan Kondusif) sehingga setiap siswa dapat berkembang secara optimal dalam situasi aman dan nyaman; (b) Menumbuhkan semangat untuk maju secara intensif dan kompetitif kepada warga sekolah melalui pembelajaran terpadu; (c) Menumbuhkan peng-hayatan dan pengamalan terhadap ajaran agama yang dianut dan budaya bangsa sehingga menjadi sumber kearifan dalam bertindak.

Berdasarkan visi dan misi tersebut, sekolah merumuskan tujuan seperti berikut: (1) Siswa beriman dan bertaqwa kepada Tuhan Yang Maha Esa dan berakhlak mulia; (2) Memiliki kecakapan hidup; (3) Mengenali dan mencintai bangsa, masyarakat dan kebudayaan; (4) Meraih prestasi akademik maupun non akademik minimal tingkat Kecamatan; (5) Menguasai dasar-dasar ilmu pengetahuan dan teknologi sebagai bekal untuk me-lanjutkan ke sekolah yang lebih tinggi; (6) Menjadi sekolah yang diminati di masyarakat; 
(7) Menjalankan pola hidup bersih, sehat serta peduli lingkungan sekitar dan dapat memanfaatkan dalam kehidupan sehari-hari.

\section{Evaluasi Konteks MBS.}

Pengelolaan pendidikan dalam era otonomi daerah, menyiratkan bahwa peran dan tanggung jawab pelaksanaan pendidikan telah diserahkan kepada daerah, termasuk tanggungjawab dalam meningkatkan mutu pendidikan. Selanjutnya pengelolaan pendidikan diserahkan kepada sekolah di mana sekolah diberikan kewenangan untuk mengelola sekolahnya.

Demikian halnya dengan SD Negeri Genuk 01, dengan adanya otonomi sekolah tersebut menjadikan sekolah lebih mandiri dan mampu mengembangkan program-program yang sesuai dengan kebutuhan dan potensinya. Selain itu sekolah juga lebih leluasa untuk mengelola sumberdaya yang tersedia di sekolah tersebut.

Namun dalam pengelolaan keuangan, sekolah belum diberikan keleluasaan secara penuh seperti yang tersirat pada kebijakan MBS. Sehingga hal itu cukup menyulitkan sekolah untuk memenuhi kebutuhan sekolah yang tidak bisa didanai dari dana BOS. Salah satu cara yang bisa ditempuh oleh sekolah yaitu dengan melibatkan masyarakat atau wali murid untuk ikut berperan secara aktif membantu sekolah dalam memenuhi kebutuhan tersebut.

Aspek lain yang melatarbelakangi terselenggarakannya MBS adalah kondisi geografis dan kondisi sosial ekonomi masyarakat. Kondisi dan kesesuaian daerah sekitar SD Negeri Genuk 01 ditinjau dari sosial budaya kehidupan masyarakat dapat dikatakan bahwa masyarakat sekitar mendukung pelaksanaan MBS. Masyarakat berpartisipasi dalam hal keamanan dan kenyamanan sekitar sekolah. Hal ini sesuai dengan pendapat Raharjo (2004:9), bahwa lingkungan sekolah yang aman dan tertib, dapat menciptakan suasana proses belajar mengajar yang nyaman dan efektif.

Kondisi Alam sekitar SD Negeri Genuk 01 yang jauh dari gangguan bencana alam dan jarak yang terjangkau peserta didik dapat mendukung penyelenggaraan pendidikan di sekolah dan memiliki potensi besar untuk sukses dan berkembangnya MBS. Keterjangkauan peserta didik menuju ke sekolah dijelaskan dalam ketentuan dari standar pelayanan minimal bidang pendidikan, yang intinya bahwa harus tersedia satuan pendidikan dalam jarak yang terjangkau dengan berjalan kaki yaitu maksimal tiga kilometer untuk SD/MI. Kerukunan antara umat beragama dan adat istiadat masyarakat di sekitar SD Negeri Genuk 01 tergolong kondusif. Masyarakat juga memiliki keyakinan terhadap penyelenggaraan pendidikan di SD 
Negeri Genuk 01. Hal itu terbukti sebagian besar masyarakat di sekitar sekolah mempercayakan anak-anaknya untuk belajar di sekolah tersebut.

Keberlangsungan proses pendidikan tidak terlepas dari latar belakang orang tua peserta didik, terkait dengan kondisi sosial ekonominya. Dilihat dari tingkat pendidikan orang tua yang rata-rata masih tergolong rendah dan sumber mata pencaharian sebagai karyawan pabrik, berpengaruh terhadap prestasi peserta didik. Orang tua mempunyai tanggung jawab untuk memberikan perhatian pada anak selama di rumah. Tetapi kenyataan yang ada, waktu orang tua banyak tersita di tempat bekerja, sehingga nyaris tidak ada kesempatan untuk mendampingi anak belajar.

Tanggungjawab pendidikan bukan semata-mata menjadi tanggungjawab sekolah, namun juga menjadi tanggung jawab masyarakat atau orang tua untuk ikut serta berperan dalam meningkatkan mutu pendidikan. Pentingnya partisipasi masyarakat diamanatkan dalam UU Sisdiknas Pasal 9 bahwa: "Masyarakat berkewajiban untuk memberikan dukungan sumber daya dalam penyelenggaraan pendidikan"; dan Pasal 54 Ayat (1) dan (2) "Peran serta masyarakat dalam pendidikan meliputi peran serta perorangan, kelompok, keluarga, organisasi profesi, pengusaha dan organisasi kemasyarakatan dalam penyelenggaraan dan pengendalian mutu pelayanan pendidikan", serta masyarakat dapat berperan serta sebagai sumber, pelaksana, dan pengguna hasil pendidikan".

Namun kenyataan yang ada di SD Negeri Genuk 01 dukungan atau partisipasi masyarakat pada pendidikan/sekolah dalam bentuk pemikiran, fisik, dana, ataupun bidang teknis edukatif belum banyak dilakukan, sebagaimana yang diharapkan dari pelaksanaan MBS. Untuk mendapatkan dukungan dari orang tua dan masyararakat adalah dengan meningkatkan hubungan yang harmonis antara sekolah dan masyarakat. Sehingga ada rasa tanggung jawab dan partisipasi masyarakat untuk ikut serta memajukan pendidikan di sekolah tersebut akan baik dan meningkat, sehingga dapat menjembatani pemenuhan kebutuhan yang diperlukan oleh sekolah dan masyarakat itu sendiri.

\section{Evaluasi Input MBS.}

MBS bukan hanya sekedar memiliki kewenangan dalam pengelolaan pendidikan saja, melainkan mensyaratkan kemampuan dan kemandirian dari sumber daya manusia yang terlibat di dalam pengelolaan satuan pendidikan tersebut, seperti: kepala sekolah, guru, staf, serta komite sekolah. Tidak dapat dipungkiri bahwa efektivitas dan efisiensi belajar dan pembelajaran siswa di sekolah sangat bergantung kepada peran guru. Guru yang profesional sangat menentukan keberhasilan dari pendidikan. Selain itu keberhasilan suatu program 
dipengaruhi juga oleh jumlah maupun tingkat pendidikan dari personil serta kemampuannya untuk pendukung proses pendidikan itu sendiri.

Berdasarkan latar belakang pendidikan yang dimiliki, bahwa sumber daya manusia yang mendukung terlaksananya MBS di SDN Genuk 01 sudah sesuai dengan yang disyaratkan, yaitu dari faktor jumlah personil sudah lengkap dan rata-rata berpendidikan S1 termasuk guru mata pelajaran. Hal itu sesuai dengan Peraturan Mentri Pendidikan Nasional No. 16 Tahun 2007 tentang Standar Kualifikasi akademik dan Kompetensi Guru. Dengan demikian secara umum sumber daya manusia yang ada di SD Negeri Genuk 01 memiliki kemampuan dan kemandirian dalam melaksanakan tugas dan tanggung jawab yang dibebankannya

Kurikulum merupakan seperangkat rencana dan pengaturan mengenai tujuan, isi dan bahan pelajaran serta cara yang digunakan sebagai pedoman penyelenggaraan kegiatan pembelajaran untuk mencapai tujuan pendidikan tertentu (Depdiknas, 2008). Terkait dengan hal itu, maka setiap sekolah harus mengembangkan Kurikulum Tingkat Satuan Pendidikan (KTSP).

Demikian halnya dengan SD Negeri Genuk 01, setiap awal tahun pelajaran kepala sekolah bersama tim pengembang menyusun KTSP yang dikembangkan sesuai dengan kondisi sekolah, potensi atau karakteristik daerah, sosial budaya masyarakat setempat, dan peserta didik. Kurikulum yang tersusun merupakan sebuah dokumen yang akan diimplementasikan sebagai panduan proses pembelajaran pada tahun pelajaran 2014/2015 dalam masa transisi dari kurikulum 2006 ke kurikulum 2013. Dalam kurikulum tersebut tertuang visi dan misi sekolah, dengan harapan dapat dicapai dengan MBS.

Dalam dokumen KTSP SD Negeri Genuk 01, tertulis dengan jelas visi dan misi yang dirumuskan berdasarkan kondisi sekolah, diantaranya memasukkan wawasan lingkungan sebagai langkah ke depan dalam upaya mengurangi polusi udara. Dalam KTSP tersebut juga termuat tentang muatan lokal Bahasa Jawa, Tembang Jawa, dan Bahasa Inggris, serta memuat kegiatan pengembangan diri yang dilakukan dalam bentuk ekstrakurikuler.

MBS akan efektif apabila didukung oleh sarana dan prasarana yang memadai. Demikian halnya dengan SD Negari Genuk 01, menyediakan sarana dan peralatan yang cukup lengkap untuk mendukung kegiatan belajar mengajar agar dapat mencapai tujuan secara maksimal. Hal ini sejalan dengan ketentuan yang tertulis dalam UU No 20 taun 2003 tentang Sisdiknas pasal 45 ayat 1 yang menyatakan bahwa: "Setiap satuan pendidikan formal dan non formal menyediakan sarana dan prasarana yang memenuhi keperluan pendidikan sesuai 
dengan pertumbuhan dan perkembangan potensi fisik, kecerdasan intelektual, sosial, emosional, dan kejiwaan peserta didik."

Dana dan anggaran merupakan sumber daya yang sangat diperlukan untuk menunjang efektivitas dan efisiensi pengelolaan pendidikan. Hampir semua kegiatan yang ada di sekolah membutuhkan biaya. Saat ini sumber dana yang diterima SD Negeri Genuk 01 hanya berasal dari pemerintah berupa dana BOS dan dana pendamping berupa dana BOSDA. Penggunaan dana untuk kegiatan di sekolah tidak boleh menyimpang dari juknis pengelolaan dana BOS. Kondisi demikian cukup mempersulit pihak sekolah untuk menggunakan dana sesuai dengan kebutuhan sekolah secara luas. Namun secara umum dana yang ada cukup untuk mendukung terselenggaranya MBS.

\section{Evaluasi Proses MBS}

Faktor penting dalam kegiatan MBS adalah proses pengambilan keputusan. Sekolah merupakan suatu organisasi, tentu diperlukan adanya penetapan tujuan, penyusunan rencana, pengorganisasian, penempatan personil, sampai dengan tahap pelaksanaan. Semua kegiatan tersebut tidak terlepas dari proses pengambilan keputusan yang dianggap paling tepat.

Dalam penyelenggaraan MBS di SD Negeri Genuk 01, pengambilan keputusan dilakukan oleh kepala sekolah dengan melibatkan seluruh tenaga pendidik dan tenaga kependidikan. Semua saran, masukan, dan pendapat disimpulkan oleh kepala sekolah selaku pimpinan untuk menentukan langkah-langkah yang hendak diambil dalam suatu kegiatan. Hal tersebut sejalan dengan pendapat Farland (1976 dalam Rohiat 2012:20), bahwa keputusan adalah suatu tindakan pemilihan di mana pimpinan menentukan suatu kesimpulan tentang apa yang harus atau tidak harus dilakukan dalam situasi tertentu. Namun tidak semua bentuk pengambilan keputusan dilakukan oleh sekolah dengan melibatkan masyarakat, tetapi hanya pada saat membahas program-program pembangunan.

Proses pengelolaan MBS di SD Negeri Genuk 01, Kecamatan Ungaran Barat diawali dari tahap perencanaan, merupakan kegiatan awal untuk menyiapkan secara sistematis bentuk-bentuk kegiatan yang akan dilakukan untuk mencapai tujuan dari program sekolah, seperti merumuskan visi, misi, tujuan, serta rencana kerja sekolah.

Pada tahap pelaksanaan, sekolah melaksanakan program sesuai dengan pedoman yang ada. Selain itu sekolah juga menyusun struktur organisasi sekolah, menyusun dan melaksanakan kegiatan sekolah dalam keseluruhan bidang, dari bidang kesiswaan, bidang pendidik dan kependidikan, sampai dengan peran serta masyarakat. Pada tahap akhir dari proses pengelolaan MBS adalah tahap pengawasan dan evaluasi. Dalam hal ini kepala sekolah 
melaksanakan pengawasan dan evaluasi terhadap kegiatan pembelajaran dan evaluasi terhadap program kerja tahunan sekolah.

Proses pembelajaran menentukan baik tidaknya lulusan yang dihasilkan oleh sekolah. Pembelajaran yang baik cenderung menghasilkan lulusan dengan hasil belajar yang baik pula. Dalam hal ini peran guru sangat menentukan keberhasilan proses pembelajaran. Berdasarkan hasil penelitian menunjukkan, bahwa dalam pelaksanaan pembelajaran tidak semua guru di SD Negeri Genuk 01 memanfaatkan media atau alat peraga, hanya di kelas 1, 2, 4, dan 5 menggunakan media pembelajaran dengan lengkap, karena tuntutan kurikulum 2013. Peserta didik terlihat lebih aktif bertanya dan menyam-paikan pendapat, selain itu peserta didik juga tampak senang. Hal itu sesuai dengan pembelajaran PAKEM yang dikehendaki dalam MBS.

Proses evaluasi adalah tahapan dalam MBS, merupakan kegiatan penting untuk memperoleh informasi sejauh mana tingkat keefektifan dan kesuksesan pelaksanaan program sekolah. Evaluasi dilakukan oleh SD Negeri Genuk 01 secara menyeluruh, menyangkut pengelolaan semua bidang, yaitu bidang teknis edukatif atau pelaksanaan kurikulum/proses pembelajaran, bidang keuangan, bidang ketenagaan, sarana prasarana. Rumusan hasil evaluasi secara menyeluruh digunakan oleh sekolah untuk mengetahui kelebihan dan kekurangannya untuk perbaikan program tahun berikutnya dan digunakan sebagai dasar untuk menyusun rencana pengembangan dan peningkatan mutu pendidikan.

Hal itu sejalan dengan penjelasan Umaedi (2012: 6.24), bahwa hasil evaluasi sekolah secara menyeluruh salah satunya digunakan sebagai masukan bagi tindakan koreksi dan perbaikan atau penyempurnaan bagi program kerja tahun berikutnya serta penyempurnaan kebijakan pengelolaan satuan pendidikan yang bersangkutan.

\section{Evaluasi Produk MBS}

Produk atau hasil MBS di SD Negeri Genuk 01, Kecamatan Ungaran Barat, Kabupaten Semarang merupakan tahap akhir yang hendak dicapai oleh sekolah. Produk merupakan bukti nyata dari keberhasilan MBS di SD Negeri Genuk 01. Keberhasilan dari MBS di SD Negeri Genuk 01 dapat dilihat pada setiap akhir tahun pelajaran, pada saat sekolah melakukan evaluasi terhadap program tahunan sekolah.

Keberhasilan dari MBS berorientasi pada prestasi yang diraih oleh sekolah yang berupa prestasi akademik dan non akademik. Berdasarkan uraian hasil penelitian menunjukkan, bahwa pada prestasi akademik ataupun non akademik di SD Negeri Genuk 01 belum maksimal. Proses pembimbingan yang belum maksimal dalam menghadapi lomba sangat berpengaruh terhadap keberhasilan peserta didik. 


\section{SIMPULAN DAN SARAN}

\section{Simpulan}

Berdasarkan hasil analisis dan pembahasan yang dilakukan maka dapat disimpulkan bahwa pada evaluasi konteks menunjukkan bahwa pelaksanaan program Manajemen Berbasis Sekolah dibutuhkan oleh stakeholder sekolah dalam upaya meningkatkan mutu pendidikan. Program tersebut didukung dengan kebijakan pemerintah yaitu Pemberlakuan UndangUndang Republik Indonesia Nomor 32 tahun 2004, tentang Otonomi Daerah dan PP 19/2005:SNP Ps 49:1, tentang penerapan program MBS di setiap satuan pendidikan.

Dalam evaluasi input, pelaksanaan program MBS didukung dengan adanya sumber daya manusia yaitu tenaga pendidik dan tenaga kependidikan yang sesuai baik jumlah maupun kualifikasi pendidikannya, kurikulum yang sesuai, sarana prasarana yang memadai serta pembiayaan yang mencukupi untuk terselenggaranya MBS.

Evaluasi proses (Process) menunjukkan bahwa belum sepenuhnya sesuai dengan yang diharapkan dari pelaksanaan MBS, terutama pada pengambilan keputusan dan pada proses pembelajaran. Di mana proses pengambilan keputusan belum melibatkan masyarakat atau orang tua secara maksimal. Sedangkan dalam proses belajar mengajar belum semua guru menciptakan pembelajaran yang aktif, kreatif, efektif, dan menyenangkan seperti yang direncanakan dari pelaksanaan MBS.

Implementasi program MBS di SD Negeri Genuk 01 Ungaran Barat produk (output) yang dihasilkan belum sesuai dengan yang diharapkan. Hal tersebut ditandai dengan prestasi akademik terkait dengan hasil ujian sekolah belum maksimal seperti yang diharapkan oleh sekolah maupun masyarakat. Demikian pula untuk prestasi non akademik yang diraih sekolah belum optimal.

\section{Saran}

Sesuai dengan hasil evaluasi di atas maka disarankan agar implementasi program MBS di SD Genuk 1 dilanjutkan dengan perbaikan pada aspek pengambilan keputusan dan aspek proses belajar mengajar. Dalam pengambilan keputusan hendaknya Sekolah lebih melibatkan masyarakat atau orang tua secara maksimal. Sedangkan dalam proses belajar mengajar hendaknya Kepala Sekolah meningkatkan kemampuan para guru dalam menciptakan pembelajaran yang aktif, kreatif, efektif, dan menyenangkan sebagaimana dipersyaratkan dalam pelaksanaan MBS.

\section{DAFTAR PUSTAKA}


Arikunto, Suharsimi dan Jabar, Cepi Safruddin Abdul. 2008. Evaluasi Program Pendidikan. Jakarta: Bumi Aksara

Badan Standar Nasional Pendidikan, 2008. Pedoman Penyusunan Kurikulum Tingkat Satuan Pendidikan di SD. Jakarta: Ditjen manajemen Dikdas Depdiknas

Depdiknas, 2005. Paket Pelatihan 1 Peningkatan Mutu Pendidikan Dasar; Jakarta: Depdiknas

Hidayat, A dan Machali, I, 2012. Pengelolaan Pendidikan: Konsep, Prinsip, dan Aplikasi Dalam Mengelola Sekolah dan Madrasah. Yogyakarta : Kaukaba.

Kemendikbud, 2004. Standar Pelayanan Minimal Bidang Pendidikan. Jakarta: Depdikbud

Mulyasa, 2012. Manajemen Berbasis Sekolah: Konsep, Strategi, dan Implementasi. Bandung : PT Remaja Rosdakarya.

Patton, M.Q. 2006. Metode Evaluasi Kualitati. Semarang: Pustaka Pelajar

Permendiknas, 2007. Standar Kualifikasi Akademik dan Kompetensi Guru. Jakarta: Depdiknas

Permendiknas, 2007. Standar Pengelolaan Pendidikan. Jakarta: Depdiknas

Raharjo, B. 2004. Manajemen Berbasis Sekolah. Jakarta: Depdiknas.

Rohiat, 2009. Manajemen Sekolah. Teori Dasar dan Praktik. Bandung: Refika Aditama.

Tayibnapis, Farida Yusuf. 2008. Evaluasi Program dan Instrumen Evaluasi. Untuk Program Pendidikan dan penelitian. Jakarta: Rineka Cipta

Umaedi, Hadiyanto, dan Siswantari, 2008. Manajemen Berbasis Sekolah. Jakarta: Universitas Terbuka

Undang-undang Nomor 20. Tentang Sistem Pendidikan Nasional. 2003. Jakarta. Lembaran Negara.

Wirawan, 2011. Evaluasi. Teori, Model, Standar, Aplikasi, dan Profesi. Jakarta: Rajawali Pers. 